\title{
Kirsten Hempkin
}

Faculty of Arts

University of Maribor

\section{Exploring Stereotypes: Scottish and Slovene Jokes in the Classroom}

\author{
Summary
}

It is widely accepted that the use of humour and jokes in particular brings a number of benefits to the EFL teacher. Not only can jokes help to establish a relaxed learning atmosphere, they can also serve as a context in which to study particular aspects of grammar, vocabulary and culture. However, jokes based on national and regional stereotypes tend to be ignored by EFL teachers, as their potential to cause offense has seen them deemed unsuitable for classroom use.

The purpose of this paper is to present a different perspective: it is precisely the rather risky nature of these jokes which makes them ideal for classroom use, particularly in lessons with the specific aim of raising students' cultural awareness through the exploration of stereotypes.

Key words: Scottish and Slovene jokes, national and regional stereotypes, EFL classroom, cultural awareness.

\section{Raziskovanje stereotipov - škotske in slovenske šale v razredu}

Povzetek

Splošno znano dejstvo je, da sta humor in še posebej šale zelo dobrodošla pri pouku angleščine kot tujega jezika. Ne le, da šale pripomorejo k ustvarjanju sproščenega vzdušja pri pouku, ampak lahko služijo tudi kot kontekst za pouk določenih vidikov slovnice, besedišča in kulture. Vendar pa učitelji angleščine kot tujega jezika rabijo šale, ki temeljijo na nacionalnih in regionalnih stereotipih, ker so te lahko žaljive in zato neprimerne za rabo v razredu. Namen članka je prikazati, da so ravno te nekoliko problematične šale lahko idealno sredstvo pri pouku, katerega namen je razviti kulturno zavest učencev na primeru stereotipov.

Ključne besede: škotske in slovenske šale, nacionalni in regionalni stereotipi, angleščina kot tuj jezik, kulturna ozaveščenost 


\section{Exploring Stereotypes: Scottish and Slovene Jokes in the Classroom}

\section{Introduction}

The use of humour and jokes in the classroom is certainly not a novelty; indeed, a simple internet search reveals a wealth of resources devoted to appropriate classroom jokes and how to incorporate them into teaching. ${ }^{1}$ EFL practitioners suggest that there are a number of benefits to be had by using jokes in the classroom:

Firstly, humour and jokes may help contribute to a relaxed learning atmosphere, and much has been written about the importance of motivation and affect in the learning process, i.e. that a happy learner is a more effective learner. (Kristmanson 2000).

Jokes may also be used to develop specific points of grammar and vocabulary. For example, the following joke could be exploited as a context for study of the (often painful to learn) third conditional:

A little boy goes home to his dad and says: "Dad, you'll never guess, I managed to save some money today!"

"How did you do that son?" replies the dad.

"Instead of taking the bus home, I ran all the way home behind it."

"Och, you stupid boy," exclaims the dad, giving him a clip around the ear." If you had run behind a taxi you would have saved more."

The next example is perhaps rather more demanding linguistically, yet the use of the joke here serves as an example of how they may be exploited to investigate language through pun, word play and indeed dialect. A knowledge of Scots pronunciation is required to understand the punchline:

A Scot goes into a bakery and asks the shop assistant: "Is that a doughnut or a meringue?" To which the assistant replies: "Naw, you're right." The response may at first seem somewhat baffling to a non-Scots speaker, until it is pointed out that the shop assistant does not hear the customer refer to a meringue, as in a fluffy cream filled cake. Instead, she hears " ...am I wrang?", which can be translated into standard English as "...am I wrong?"

Another interesting aspect of jokes for the teacher is their use as a tool to explore culture in the classroom. They may provide, for example, an insight into different cultural beliefs and practices. Teachers may wish to investigate with their students why the following joke may seem odd or indeed even inappropriate to someone from an Asian culture:

I never forget a face, but in my mother-in-law's case I am willing to make an exception. 
According to Muqun and Lu (2006), mother and son-in-laws in Asian cultures usually enjoy a very friendly and respectful relationship which renders the stereotypical mother-in-law jokes of some western cultures (the U.K. included) incomprehensible.

In other examples, we see that specific cultural information is required to understand a joke, which could also provide a context for the study of the culture of the target language. In this example, students would need to know that within Scotland, Glasgow is often seen as a crimeridden city, and Glaswegians as dishonest:

\section{How do you address a Glaswegian in a suit? The accused.}

Or indeed, this other rather cruel example, again from a Scottish cultural context:

A bomb fell on Glenrothes yesterday, Did $£ 4.73$ worth of damage.

Glenrothes is one of the Scottish new towns, re-built in the 1970s to attract business to the area and inject much needed life into the local economy. Since then, Glenrothes has enjoyed a reputation, unfortunately justifiably, for being architecturally ugly.

It is this cultural aspect of classroom jokes that I would like to focus on, and indeed, on a body of jokes normally (some may say with good reason) ignored for classroom use. In particular, I will try to argue that jokes based on national and regional stereotypes can be exploited to develop students' cultural awareness. ${ }^{2}$ This may seem something of a paradox at first: the reason these jokes tend to be ignored by teachers is because of their potential to cause offense. However, it is precisely their rather charged or controversial nature which, I believe, makes them ideal for classroom study.

\section{The Importance of Cultural Awareness}

As ESL practitioners we are all aware of the importance of cultural awareness in the language classroom. It could certainly be argued that true communication is somehow impossible without at least a certain level of cultural awareness (Šabec and Limon 2000). As many of our students at Filozofska Fakulteta in Maribor intend to become teachers, it seems somehow especially important for them to become culturally aware: we not only expect them to use English as accurately as possible, but we also expect that they will be able to guide their own students through the maze of cultural issues themselves, hopefully in an atmosphere of openness and tolerance.

As Byram says in his definition of what makes the best teachers: "The best teacher is...the person who can help learners see relationships between their own and other cultures, can help them acquire interest and curiosity about 'otherness', and an awareness of themselves and their own cultures seen from other people's perspectives." (Byram et al. 2002, 10)

While we may all agree that developing cultural awareness or indeed intercultural competence is a must, there are certainly a number of hurdles which stand in our way. Fennes and Hapgood (1997), among others, identify stereotypes as being one of the most significant of these obstacles

I use the term 'developing cultural awareness' very broadly here to encompass not only acquiring factual knowledge of another/ other cultures, but also to include developing, as Byram (2002) describes it, the skills, attitudes and values essential to understanding other cultures. This is referred to by Byram and others as intercultural competence. 
and indeed state that one of the goals of intercultural learning is to become conscious of stereotypes and prejudices. They describe how dangerous stereotypes can be: instead of opening us up to other nations and cultures, they in a sense close us down by narrowing our perceptions of them to a reductive image of people and their habits

University students are certainly not immune to holding such stereotypes. Research carried out by Coleman (1998) found that university students are not only guilty of holding deeprooted national stereotypes, but they are very often strengthened by the kind of activities we may assume would actually rid students of them: study or work placements abroad. Although no formal studies have been carried out on the students at our faculty, through regular contact and discussion with them in our language development classes, I very strongly suspect that our students also hold the kind of deep-seated stereotypes described above. In order therefore to begin the process of exploring and ultimately challenging those stereotypes, I have developed a series of joke-based exercises which I will present here. Some are tried and tested and where appropriate, I will also discuss the reaction or response of the students to them.

The aim of the exercises is three-fold. The tasks focus initially on the content of jokes. By comparing selected jokes, some of which are based on national stereotypes and others which contain neutral cultural information, students are first asked to define a stereotype and to consider whether or not stereotypes (and indeed these jokes) are somehow harmful.

Secondly, students are asked to identify and question the truth of the stereotypes contained in jokes about Slovenes and Scots (and hopefully by extension other nationalities), encouraging them to start thinking about the way they regard other nationalties, and, also importantly, they way others view them.

Lastly, by considering how they feel about the jokes in the study (especially those based on the stereotypes held about Slovenes), our future teachers begin not only to explore the issues of political correctness and what is appropriate for the classroom, but are also given an opportunity, if required, to reconsider some of the views they express in previous tasks.

\section{Classroom tasks}

\subsection{Joke gathering}

The first step in our exercises was to gather the jokes we would use in class. This was a process the learners themselves were actively engaged in. Students were encouraged to find as many jokes about Slovenia and the Slovenes as they could, while I provided the Scottish ones. ${ }^{3}$ The only guidance they were given as to content was that they should be happy to tell the joke in front of me and their fellow classmates - this was designed to act as a kind of self-censorship measure. Students were also told that they could bring jokes in Slovene as we would translate them together at a later date.

The choice of nationalities is significant. The vast majority of our students are Slovene and for them to feel something about these jokes it is important that they can relate to them directly. I am a Scot and by happy coincidence there are a vast number of jokes based on our stereotypical national character. 
The material gathered came from a number of sources: mostly the internet (including YouTube), joke sections in newspapers and foreign friends.

\subsection{Analysis}

Once the material was gathered, the jokes were classified into the following sections: jokes about Slovenia and the Slovenes, jokes about Scotland and the Scots, and the jokes Scots make about other nationalities. Each set of jokes has a set of accompanying exercises - language exercises such as matching or gap fill activities (to complete the joke), analysis and reflection activities, followup discussion and writing tasks.

We will consider each of these tasks in turn.

\subsection{Task One: Defining stereotypes}

In the first set of tasks the focus lies in defining stereotypes and encouraging the students to reflect on the stereotypes they hold and whether or not they consider them to be harmful. The following joke based on common European stereotypes is presented to the students and they are asked to consider what hell must look like if this is an image of heaven: Heaven is a place where the police are British, the cooks are French, the mechanics are German, the lovers are Italian and the Swiss are in charge of organisation.

Once they have come up with their own suggestions, we compare them with the actual ending of the joke:

Hell is a place where the police are German, the cooks are British, the mechanics are French, the lovers are Swiss and everything is organised by the Italians.

The students in previous classes were able to very easily explain why this is such a hellish vision, readily providing an appropriate stereotype for each nation: the food in the U.K. is awful, the French are better at poetry and the arts...etc. At this point, students are asked to discuss with a partner which other stereotypes they knew of for other European countries, and again, they had little difficulty in completing this task.

The next step is to complete a task based on jokes about Slovenia. The content here is slightly different, however. Rather than featuring stereotypes, the following jokes contain cultural information (the fact that Slovenia is a small country) which it is necessary to know in order to get the joke. First and punchlines are matched to complete the joke; a small selection of the jokes follows:

Why should you be careful opening an umbrella in Ljubljana?

You might take someone's eye out in Maribor

What is the shortest joke in the world?

A couple were walking along the Slovene coast. 
Why don't Slovenes need mobile phones?

They can yodle from one end of the country to another.

Once the students had completed the matching task they were asked to decide what the joke played on. They were then asked to compare the content of the Slovenia jokes with the joke about heaven and hell and see if they could find any differences between the types of material they contain.

While this task proved relatively straightforward and the students were able to spot the differences between stereotypes and cultural information fairly easily, it proved slightly trickier for the students to decide upon an appropriate definition of a stereotype. Students were split into pairs and each pair asked to produce a definition, which was then put together to make a class definition. The ideas produced in this exercise include:

Stereotypes are negative beliefs we have about other people.

There is an element of truth in stereotypes.

Stereotypes are exaggerated ideas.

Once a class definition was agreed upon, we compared it to an 'expert' opinion taken from an internet language teaching forum. ${ }^{4}$ Students were then invited to revise their own definitions if they so wished.

The follow-up discussion to this activity is certainly enlightening. Students were asked if they felt that stereotypes could be somehow harmful, as claimed in the definition of stereotypes above. There was some resistance to this idea, as the general feeling was that people don't take stereotypes so seriously. Certainly, very few of the students made the same link that Fennes and Hapgood (1997) make between stereotypes and prejudice. ${ }^{5}$

There are a variety of exercises available to encourage students to see the connection between stereotypes and prejudice. Byram (2002) suggests a text-based approach, using newspaper articles on the theme of immigration, for example, to alert learners to the expressions we use to describe those who are perceived to be different to us. Sercu (1998) also favours a language and culture integrated approach, encouraging learners to discuss the implications for meaning in the change of conjunction in the following sentences: She is nice but she is French; she is nice because she is French; she is nice and she is French.

I have used the following exercise in class with some success. Students are given a list of nationalities (it could be those above), then the list is expanded to include ethnic groups common in Slovenia (Slovene, Roma, Bosnian, Croatian, British). This is the only information initially provided.

4 Obviously, definitions of stereotypes vary widely. The one we used in class (at http://the english dept.tripod.com/stereo2. $\underline{h t m}$ ) was full, clear and, importantly for our purposes, very explicitly made the link between stereotypes and prejudice.

5 Our students are certainly not alone in this view. Beeman (1996) cites his own classroom experience of students expressing similar opinions, which he points out is entirely consistent with a number of studies on prejudice. 
They are asked to work on their own to answer the following questions and then justify their answers to their neighbours:

Who would you most and least like to:

- have as a neighbour?

- employ in your company?

- go for a coffee with?

- rent an apartment to?

- baby-sit your child?

- have as a student in your class?

This exercise is certainly far from sophisticated (although we could certainly argue that the stereotypes we are dealing with are also fairly crude), yet it seems to work as it forces us to confront head on the stereotypical beliefs we hold.

\subsection{Task Two: Identifying and challenging Scottish and Slovene stereotypes}

The next task requires students to consider Scottish jokes and stereotypes. The first step is a simple gap fill exercise, where one word from the list provided completes the joke. Each joke contains an example of a stereotype about the Scots and the way we are perceived by others. (The word underlined indicates the missing term on the worksheet.)

A Scotsman and woman have been shipwrecked on a desert island. They have very little food left, not a lot of water and the sun is beating down relentlessly.

"Well," says the husband. "I suppose it could have been worse."

"Aye," says the wife. "We might have bought a return ticket."

Dr. McGregor was examining the patient. "Well, I can't see much wrong with you. It must be due to drink." The patient replies understandingly, "That's alright, I'll come back when you're sober."

(This joke was particularly popular among the students.)

A Scotsman was sitting in a bar, knocking back whisky after whisky. The barman asked him if he was alright. "Well," said the Scotsman, "drinking is the only way I can get over my accident." "What accident was that?" says the barman. The Scotsman tearfully replies "I knocked one over with my elbow!"

The students very quickly ascertain that the first joke plays on the Scottish stereotype of being mean with money, the second on their love of alcohol (especially whisky) and the third manages to combine both of those stereotypes.

Once the students had gathered the required information about Scotland, it was time to turn their attention to Slovenia. Here, the jokes which they had previously collected were put into use. Again, a selection of the jokes follows: 
(This joke is tricky to translate into English as it plays on the verb delati (to work or do) A Bosnian and a Slovene were walking in the desert one day when they fell into a hole.The Slovene says "No, kaj bomo zdaj delali!?" (What are we going to do now? Literally-could also mean work)

The Bosnian replies: "Typical Slovene-always thinking about work!" (It is also worth noting here the stereotype of Bosnians being lazy, in stark contrast to the hardworking Slovene.)

A farmer finds a magic lamp one day. Giving it a polish, he releases a good fairy who has been trapped inside. To reward him for releasing her, she grants him three wishes, but to stop him becoming too greedy, anything he wishes for himself his neighbour will enjoy multiplied. His first wish is for a new car, the second for a busty mistress, the third that his cow suffers a mild heart attack! ${ }^{6}$

The students also provided an example of a joke which is actually an animated cartoon entitled 'Mi smo Slovenci, found on YouTube. The cartoon originates from Croatia, and features a row of figures animated in the style of the Southpark cartoon singing a song (best described as a little risqué), the refrain of which, translated from the Croatian is We are Slovenes and we live better than you.

Students concluded that the jokes about Slovenes suggest that they are hard-working, serious, superior and jealous of others.

It is perhaps worth mentioning here that the first observation the students made regarding the jokes was that there were, they felt, very few jokes about Slovenes as a nation and they thought that could be attributed to the fact that Slovenia is still relatively young, and, in some respects, relatively unknown. As one student so succinctly put it:

Why would anyone make jokes about us if they don't know who or where we are?

Some in the class felt that the lack of jokes is due to the fact that Slovenes take themselves too seriously and don't like to make jokes at their own expense.

Many of the students said that it was much easier to find jokes about the regions of the country, which perhaps reflects the fact that Slovenia, although small, does have a number of very distinct regions, with their own particular geography, climate and dialect. For that reason, we included some regional jokes in our exercises. Here, the initial task was that the jokes had to be completed by inserting the correct region or inhabitant of that region, for example:

A man from (Gorenjska) is lying on his death bed.

He calls out: Son, are you here?

The son replies: Yes, father, I am.

The man calls out again: Daughter, are you here?

The daughter replies: Yes, father, I am.

6 This one of the naj mu krava crkne! jokes, often told in a slightly different version to play on the supposed stinginess of the Gorenci. The farmer wishes that the cows of his neighbours should die, and then his own. When the fairy expresses surprise he claims that then no-one will bother him for milk. 
The man calls out a third time: Wife, are you here?

The wife replies: Yes, husband, I am.

The dying man calls out again: Well, if you are all here with me, then why the bloody hell is the kitchen light on?

Once the gap-fill task is completed, students are asked to compile a list of adjectives which would describe the regions featured in the jokes: Gorenjska-mean, Ljubljana (the capital)-arrogant, Dolenjska/Štajerska-drunks, Prekmurje-economically backward.

An obvious question followed: do you think that you personally are any of those things? Are these a fair assessment of the Slovene character? Can there be such a thing as a national character? The point here of course being that if these stereotypes don't hold true for Slovenes, then why should they for other nations.

The next step involves a 'round the wall' activity, where different jokes are placed around the room. Here, the content is slightly different. Instead of general stereotypes about the Scots, there are jokes about how the Scots see themselves and other nationalities. The class was given a list of questions to answer as they worked their way around the room to see what they could find out about the following topics:

Scottish views of the English/Irish. (English arrogant, ignorant about Scotland, superior. Irish often the butt of jokes, not particularly clever, often the fool)

Scottish and American relations. (Americans see themselves as superior to Scots, everything bigger in the U.S.A)

Relations between Edinburgh and Glasgow. (Rivalry between the two cities: Edinburgh inhabitants considered arrogant, Glaswegians common, Glasgow crimeridden).

Views of Glasgow and Aberdeen.(Aberdonians meanest people in Scotland). The character of the typical Scot (Jock). (The innocent, naïve character, perfect foil to the arrogant Englishman, slightly 'daft', plays bagpipes etc...)

How the Scots see themselves. (Ironic top ten reasons to be Scottish-weather, terrible at sports, good at bar fights and drinking, not English...)

The following jokes based on Scottish attitudes toward the English nicely illustrate the type of joke used in the above exercise. The English are often depicted as arrogant, and ignorant about Scotland, yet the jokes often imply that the Scots have a fairly high opinion of themselves, while the second joke here plays on the somewhat frosty relations the two countries enjoy:

When God was making Scotland, he created a country with fabulous scenery, full of lush greenery, deep lochs and high mountains. He created a people of warmth and character, and a language of great beauty and poetry. A Scotsman asks God, "Oh Lord, what have we done to deserve this?" God replies, "Better not thank me yet, just wait until you see the neighbours I'm giving you!" 
A visitor to Scotland was walking through a farmer's field one day when he spotted a pool of water. He was thirsty and began to drink from it, scooping the water out with his hand. When the farmer saw what he was doing, he cried, "Laddie, dinnae drink fae there, it's fu' ae coo keech!" (Mister, don't drink from there, it's full of cow shit!" The visitor didn't understand and called back, "Speak English please, I'm English!" To which the farmer replied, "Use two hands, you'll get more that way!"

After we had analysed the Scottish jokes above, students were asked to comment on whether there were Slovene equivalents for the above jokes, and of course there were. The Edinburgh- Glasgow jokes, with Edinburgh as sophisticated/arrogant and Glasgow down-to-earth/uncivilised, translates very neatly to the rivalry enjoyed by Ljubljana and Maribor. Bosnians take on the role of the Irish in Slovene jokes, and the Irish character, stereotypical Paddy, is actually taken by two characters, Mujo and Haso, whose short dialogues (often in a pidgin Slovene, or in Bosnian itself) leave the audience in no doubt as to their rather limited intellect. The character of Jock is Janezek in the Slovene context and he plays the role of the innocent in a number of contexts: at school, with his parents, in encounters with the police. The perhaps rather dubious honour of replacing the English goes to the Croatians, and indeed the above joke about the traveller drinking the water in the farmer's field has an almost direct equivalent in Slovene based on a Croatian eating poisonous mushrooms. The students certainly interpret this as a sign of the times, as according to them, Croatian jokes are a fairly recent phenomenon in Slovene culture. Their emergence reflects the fact that the two countries are not only now independent but that they have enjoyed somewhat frosty relations of late.

As a follow-up to this task, the students were asked to consider the following questions and their responses were discussed in class. Do they think it is in any way significant that, for example, the Scots laugh at the Irish, and the Slovenes at the Bosnians? Does that tell us anything about the nature of jokes or stereotypes themselves? Do they think it weakens or strengthens the stereotypes contained in these jokes to know that every nation has someone who serves as the butt of the joke. (In some of the classes we were fortunate to have Erasmus exchange students from Turkey and Poland who were able to provide an insight into the national and regional stereotypes their jokes are based on.)

There is one further task students should complete, and that is to consider, having heard jokes about Slovenia and the Slovenes (national and regional stereotypes), how they feel about the content of them. The purpose of this task is two-fold: to probe the answers they provided in the first task of defining stereotypes and also to consider, by exploring whether or not they were upset by the jokes, to decide if they would use these jokes in the classroom themselves. Students are asked to place the jokes in the following four categories:

Those which upset/offended them or made them feel uncomfortable.

Those they would tell to friends and/or family.

Those they would use in the classroom.

Those they would not use in the classroom.

The replies here were rather illuminating: the answers students gave here quite clearly display some rather confused thinking as they seem to contradict the answers given in the very first task asking 
them to define stereotypes. Instead of dismissing the jokes as harmless (having previously stated that people don't take stereotypes seriously), students reported that some of the jokes may actually upset them. The key factor they identified is who is actually telling the joke. While it seems to be acceptable to tell a joke about Maribor as long as you are not from Ljubljana, by the same token it is fine to tell a joke about Slovenia or the Slovenes as long as you are not Croatian.

While previously claiming that there is an element of truth in stereotypes (or else why would they exist?) the students claimed that in some jokes the stereotype was quite clearly not true. Students often brushed aside suggestions that jokes about their particular region could be offensive to them as they know them not to be true. Some answers suggest that students apply the rule about whether stereotypes are true or not selectively, conceding that when a negative stereotype applies to them they are less likely to accept it as true. ${ }^{7}$

As for the use of jokes based on stereotypes in the classroom, a range of opinions were expressed. Some of our future teachers felt that they would avoid any kind of jokes based on stereotype, as it is impossible to judge in advance who may be offended by them. This holds especially, they felt, for jokes based on near stereotypes (Bosnian, Serbian, Croatian, Montenegrin) as Slovene classrooms often consist of learners with close ties to (parents/grandparents and other relatives) neighbouring countries. Some felt more comfortable with jokes based on somehow less controversial stereotypes - judging that it was more appropriate to use those relating to the Scots or the English, or indeed other English-speaking cultures. A very small group of students took a rather more robust approach, stating that it is important that we are all able to laugh at ourselves, and we should not be afraid of using such jokes in the classroom.

This particular debate led in some classes to a wider (and very fruitful) discussion on appropriate humour in the classroom and also more generally to the kind of topics and themes our future teachers felt they would be comfortable using in their own classroom.

\subsection{Tackling Stereotypes}

How then should we challenge the stereotypes we come across in these tasks and in the course of our language learning or teaching? The tasks I have developed for this purpose are based on two main approaches. The first is to 'knock down' the stereotypes with hard facts. There is an incredible amount of information available about Scotland and Slovenia, and I actively encourage our students to explore questions they have with the resources open to them. ${ }^{8}$ Another method of tackling these stereotypes is to personalise them. With the use of social networking sites, ${ }^{9}$ students are able to access and set up contact with real individuals from practically any country they like, hopefully encouraging them to see past any fixed ideas they may have about attitudes and behaviours.

This is again entirely consistent with studies on stereotype and prejudice as cited by Beeman (1996)

http://www.gov.si and http://www.scotland.gov.uk are both excellent sources of information about Slovenia and Scotland respectively.

$9 \quad \underline{h t t p: / / w w w . f a c e b o o k . c o m}$ and $\underline{h t t p: / / w w w . b e b o . c o m}$ are perhaps the most popular examples of social networking sites at present. 
The other approach is to 'blow up' the stereotypes rather than knock them down. This is the approach Dlaska (2000) recommends, describing how the stereotype is then hopefully rendered "unreliable". Here I place the focus mostly on writing tasks. The first one is to write a personal ad for Scots seeking Slovenes e.g. Jock urgently needs a Mojca. Hard-drinking bagpipe playing ginger-bearded hunk seeks...students should complete the task for Mojca. Another writing exercise asks students to write a diary extract for a day in the life of a typical Slovene, trying to incorporate as many stereotypical features as possible (names, food, hobbies, drinks).

The Scottish example begins something like this: Jock Mctavish wakes up to the sound of bagpipes, jumps out from underneath his tartan blanket, and goes to the drinks cabinet for his first whisky of the day...

Writing the top ten reasons to be Slovene has proved popular with our classes. Students have to look ironically at why it is fabulous to be a Slovene. A selection of their ideas follows:

When abroad, you can talk about people standing next to you, cos no-one understands Slovene anyway; Not everyone gets to live in a chicken-shaped country; You never get fed up of saying 'No, Bratislava is not the capital... Yes, we do have electricity...'

\section{Conclusion}

While EFL practioners may be justifiably hesitant about using jokes based on national stereotypes in the classroom, they should certainly not completely rule out their use. As I hope to have demonstrated in this paper, this type of joke provides an ideal platform for the exploration and ultimately the challenging of what can be often very deeply ingrained stereotypes held by our students. The exercises are certainly not designed to somehow completely resolve the problem of stereotypes, however, they do go some way to probing attitudes and beliefs about them and hopefully triggering the process of reconsidering them. Our own experience has certainly shown that students need help and guidance in clarifying their attitude toward stereotypes - not only in terms of coming to an understanding of what they actually are but also in terms of figuring out their somewhat confused and contradictory beliefs about them, in particular about whether or not they are actually harmful. The joke-based exercises also provide our future teachers with a concrete example of a controversial topic (should we use jokes featuring national stereotypes?) and an opportunity to consider how they would deal with it in their own classroom. By being encouraged to confront and reconsider their ideas, our students are certainly taking a step in the right direction toward raising their cultural awareness and eventually becoming the type of best teacher Byram describes. 


\section{Bibliography}

Byram, M., B. Gribkova, and H. Starkey. 2002. Developing the Intercultural Dimension in Language Teaching. A Practical Introduction for Language Teachers. Strasbourg: Council of Europe. http://www.coe.int (accessed 11 May 2008)

Beeman, M., and W.R. Volk. 1996. Challenging Ethnic Stereotypes: A Classroom Exercise. Teaching Sociology 24, no. 3: 299-304. http://www.jstor.org/pss/1318744 (accessed 3 Sep 2008)

Coleman, J.A. 1998. Evolving intercultural perceptions among university language learners in Europe. In Language Learning in Intercultural Perspective, eds. M. Byram and M. Fleming, 45-76. Cambridge: Cambridge University Press.

Dlaska, A. 2000. Integrating Culture and Language Learning in Institution-wide Language Programmes. Language Culture and Curriculum 13, no. 3: 249-63. http://www.multilingual-matters.net (accessed 26 June 2008)

Fennes, H., and K. Hapgood. 1997. Intercultural Learning in the Classroom. London and Washington: Cassel.

Kristmanson, P., 2000. Affect in the Second Language Classroom: How to create an emotional climate. Reflexions 19, no. 2: 1-5.

Muqun, W., and Lu, W. 2006. The functions of humour in classroom instruction. Asian EFL Journal 16, no. 2. (0n-line) http://www.asian-efl-journal.com/pta october 06 wm\&wl.php (accessed 16 May 2008)

Šabec, N., and D. Limon. 2000. Across Cultures. Maribor: Založba Obzorja.

Sercu, L. 1998. In-service teacher training and the acquisition of intercultural competence. In Language Learning in Intercultural Perspective, eds. M. Byram and M. Fleming, 255-89. Cambridge: Cambridge University Press. 